\title{
New Hemisynthetic Oleanane Saponin with Antimicrobial Activities
}

\section{Cyrille Ngoufack Tagousop1,2*, Jean-De-Dieu Tamokou33, Leonel Donald Tsamo Feugap², Dominique Harakat ${ }^{4}$, Laurence Voutquenne-Nazabadioko5, David Ngnokam²}

\footnotetext{
${ }^{1}$ Department of Basic Scientific Studies, University Institute of Technology, University of Ngaoundere, Ngaoundere, Cameroon ${ }^{2}$ Research Unit of Environmental and Applied Chemistry, Department of Chemistry, Faculty of Science, University of Dschang, Dschang, Cameroon

${ }^{3}$ Research Unit of Microbiology and Antimicrobial Substances, Department of Biochemistry, Faculty of Science, University of Dschang, Dschang, Cameroon

${ }^{4}$ Service Commun d'Analyses, Institut de Chimie Moléculaire de Reims (ICMR), CNRS UMR 7312, Reims, France ${ }^{5}$ Groupe Isolement et Structure, Institut de Chimie Moléculaire de Reims (ICMR), CNRS UMR 7312, Reims, France Email: *cyrilngoufack@yahoo.fr
}

How to cite this paper: Tagousop, C.N., Tamokou, J.-D.-D., Feugap, L.D.T., Harakat, D., Voutquenne-Nazabadioko, L. and Ngnokam, D. (2021) New Hemisynthetic Oleanane Saponin with Antimicrobial Activities. Advances in Biological Chemistry, 11, 1-11.

https://doi.org/10.4236/abc.2021.111001

Received: November 14, 2020

Accepted: January 11, 2021

Published: January 14, 2021

Copyright $\odot 2021$ by author(s) and Scientific Research Publishing Inc. This work is licensed under the Creative Commons Attribution International License (CC BY 4.0).

http://creativecommons.org/licenses/by/4.0/

(c) (i) Open Access

\begin{abstract}
A new hemisynthetic oleanane saponin: 4',2",3",4",6"-penta- $O$-acetyl-6'- $O$ methyl-3- $O$ - $\beta$-D-glucopyranosyl-( $1 \rightarrow 2)-\beta$-D-glucuronopyranosyl oleanolic acid (2) was obtained after acetylation and methylation reaction on $3-O-\beta$-Dglucopyranosyl-( $(1 \rightarrow 2)-\beta$-D-glucuronopyranosyl oleanolic acid (1). Its structure was established by extensive analysis of $1 \mathrm{D}-\left({ }^{1} \mathrm{H},{ }^{13} \mathrm{C}\right), 2 \mathrm{D}-(\mathrm{COSY}, \mathrm{HSQC}$ and $\mathrm{HMBC}$ ) NMR data in conjunction with mass spectrometry (HRTOFESIMS). The evaluation of antimicrobial activities using microdilution method showed that, reaction product (2) presented the lowest values of MIC against E. coli $(\mathrm{MIC}=16 \mu \mathrm{g} / \mathrm{mL}), S$. aureus $(\mathrm{MIC}=8 \mu \mathrm{g} / \mathrm{mL})$, C. tropicalis $(\mathrm{MIC}=16 \mu \mathrm{g} / \mathrm{mL}) C$. albicans $(\mathrm{MIC}=8 \mu \mathrm{g} / \mathrm{mL})$ compare to the substrate (1) against the same microbial strains: $E$. coli $(\mathrm{MIC}=32 \mu \mathrm{g} / \mathrm{mL}$ ), S. aureus (MIC $=16 \mu \mathrm{g} / \mathrm{mL}$ ), C. tropicalis $(\mathrm{MIC}=32 \mu \mathrm{g} / \mathrm{mL}$ ), C. albicans $(\mathrm{MIC}=16 \mu \mathrm{g} / \mathrm{mL})$. These results indicate that, acetylation and methylation reactions of compound 1 increase its antimicrobial activities against the tested microorganisms.
\end{abstract}

\section{Keywords}

Saponin, Acetylation, Methylation, Antimicrobial Activities

\section{Introduction}

Saponins are natural compounds that widely occur in the plant kingdom and 
they are constituents of more than 100 family plants including endophytic fungi of terrestrial and marine origin. They are divided into two groups namely steroidal and triterpenoid saponins [1]. Their chemical structures are composed of a fat-soluble nucleus (aglycone) that is either a triterpenoid (C-30) or neutral or alkaloid steroid (C-27) attached to one or more side chains of water-soluble sugars (glycone) through ester or ether linkages to the aglycone nucleus at different carbon sites [2]. Based on the number of sugar chains attached to aglycone, saponins are categorized into mono, di and tridesmosidic. In monodesmosidic saponins, sugar chain is usually attached to C-3 and in bidesmosidic saponins, there are usually attached firstly to the position C-3 and either at position C-28 (Triterpenoid saponins) through an ester linkage or at C-26 (Frustanol saponins) through an ether linkage. D-glucose (Glc), D-glucuronic acid (GlcA), D-galactose (Gal), D-galacturonic acid (GalA), D-xylose (Xyl), D-fucose (Fuc), L-rhamnose (Rha) and L-arabinose (Ara), are the most common monosaccharides attached to aglycone. The nature and the functional groups on the aglycone moiety as well as nature and number of sugars can vary greatly, resulting in diverse group of saponins [2] [3]. Many biological activities of saponins have been reported such as antibacterial, antifungal, antiviral, insecticidal, molluscicidal, anti-inflammatory, anti-ulcer, haemolytic and hepatoprotective activities [4]-[10]. The structural complexity in the saponins reflected in their diversity of physicochemical, pharmacological and biological properties and led to the saponins as commercially important with wide variety of applications in food, cosmetics and pharmaceutical sectors [11]. Consider the variety of applications of saponins, chemical transformations could be carried out to enhance their biological activities [12]. The acetylation and methylation reactions carried out by Penders and Delaude, 1994 [13] on six oleanane saponins isolated from Melanthera scadens let to six hemisynthetic derivatives. However, the evaluation of their biological activities has not been realized. In the aims to determine the influence of these types of reactions on the antimicrobial activities of oleanane saponins, we decided to perform acetylation and methylation reactions on 3-O- $\beta$-D-glucopyranosyl-( $1 \rightarrow 2)-\beta$-D-glucuronopyranosyl oleanolic acid previously isolated from Melanthera elliptica [10] and evaluate the antimicrobial activities of substrate and reaction product against pathogenic phenotypes selected on the basis of their relevance as human pathogens.

\section{Material and Methods}

\subsection{Extraction, Isolation and Characterization of Substrate}

Extraction, isolation and characterization of $3-O-\beta$-D-glucopyranosyl- $(1 \rightarrow 2)-\beta$ D-glucu-ronopyranosyl oleanolic acid (1) were performed by a method previously described by Tagousop et al. 2018 [10].

\subsection{Hemisynthesis and Purification}

The reaction was carried out using the method previously described by Penders 
and Delaude, 1994 [13] with some modifications (Scheme 1). In fact, in a 100 $\mathrm{mL}$ flask containing $50 \mathrm{mg}(0.06 \mathrm{mmol})$ of substrate (compound 1$), 25 \mathrm{~mL}$ of diazomethane and $25 \mathrm{~mL}$ of the pyridine-acetic anhydride mixture $(1: 1, \mathrm{v} / \mathrm{v})$ was introduced. The flask was kept at ambient temperature $\left(25^{\circ} \mathrm{C}\right)$ with magnetic stirring and the reaction was monitored on a TLC plate. After $24 \mathrm{~h}$, distilled water $(25 \mathrm{~mL})$ was added and the mixture was introduced into a separating funnel and $100 \mathrm{~mL}$ of EtOAc was added. After separation of the two phases, organic phase was dried on a rotary evaporator under reduced pressure to give $79 \mathrm{mg}$ of residue. Purification on silica gel $(0.063-0.200 \mathrm{~mm})$ column chromatography $(10 \times 200 \mathrm{~mm})$ of this residue using an isocratic elution with the mixture hexane-EtOAc $(2: 8, \mathrm{v} / \mathrm{v})$ yielded $54.89 \mathrm{mg}(85.6 \%)$ of compound 2.

\subsection{Chromatographic Methods}

Silica gel 60 Merck, 70 - 230 mesh was used to perform column chromatography while pre-coated silica gel $60 \mathrm{~F}_{254}$ (Merck) plates, were used to perform thin layer chromatography. The spots were visualized by spraying with $10 \% \mathrm{H}_{2} \mathrm{SO}_{4}$ and heating at $100^{\circ} \mathrm{C}$ for $2 \mathrm{~min}$.

\subsection{NMR Analysis}

The 1D ( ${ }^{1} \mathrm{H}$ and $\left.{ }^{13} \mathrm{C}-\mathrm{NMR}\right)$ and 2D (COSY, NOESY, HSQC and HMBC) spectra were performed in deuterated solvents (DMSO- $d_{6}$ ) on Bruker Avance III 600 spectrometer at $600 \mathrm{MHz} / 150 \mathrm{MHz}$. All chemical shifts $(\delta)$ were given in parts per million (ppm) with reference to tetramethylsilane (TMS) as internal standard and the coupling constants ( $/$ ) are in $\mathrm{Hz}$.

\subsection{Spectrometric Analysis}

The mass spectra (HR-TOFESIMS) were carried out on Micromass Q-TOF micro instrument (Manchester, UK). Samples were introduced by direct infusion in a solution of $\mathrm{MeOH}$ at a rate of $5 \mu \mathrm{L} / \mathrm{min}$.

\subsection{Microorganisms}

The microorganisms used to determine the antimicrobial activities consisted of
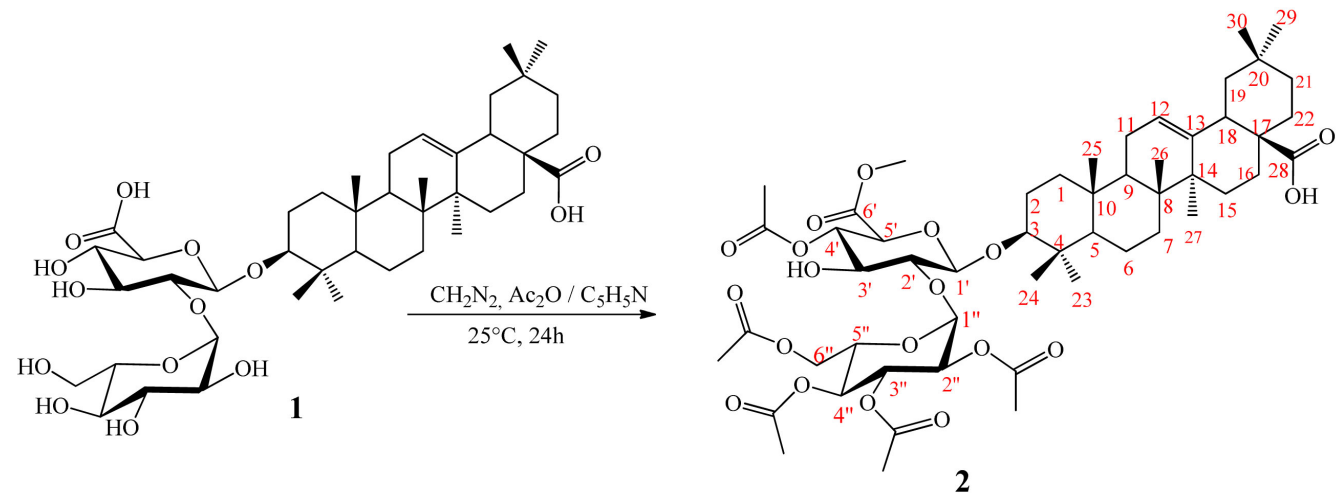

Scheme 1. General procedures used for semi-synthesis of compound 2. 
three strains of bacteria (Escherichia coli S2, Staphylococcus aureus ATCC 25923 and Shigella flexneri SDINT) and three yeast strains (Candida tropicalis, Candida albicans ATCC 9002 and Cryptococcus neoformans IP 95,026) collected from the Research Unit of Microbiology and Antimicrobial Substances of the University of Dschang and provided from the University of Kolkata in India (for bacterial strains) and the "Institut Pasteur de Paris", France (for fungal strains). These bacterial and fungal species were grown at $37^{\circ} \mathrm{C}$ and maintained on nutrient agar (NA, Conda, Madrid, Spain) and Sabouraud Dextrose Agar (SDA, Conda) slants respectively.

\subsection{Determination of Minimum Inhibitory Concentration (MIC) and Minimum Microbicidal Concentration (MMC)}

The minimum inhibitory concentration (MIC) values were determined using the broth microdilution method previously described by Clinical and Laboratory Sandards Institute (1997; 2009) [14] [15] with some modifications in terms of final concentration of samples and solutions of inocula. In fact, each sample was dissolved in dimethylsulfoxide diluted to $10 \%(\mathrm{v} / \mathrm{v})$. The solution was then added to Mueller-Hinton Broth (MHB) for bacteria or Sabouraud Dextrose Broth (SDB) for yeasts to give a final concentration of $8192 \mu \mathrm{g} / \mathrm{mL}$ (instead of 4000 $\mu \mathrm{g} / \mathrm{mL}$ ). This was serially diluted to a concentration range of 0.125 to 4096 $\mu \mathrm{g} / \mathrm{mL} .100 \mu \mathrm{L}$ of each concentration were subsequently added to each well (96-well microplate) containing $95 \mu \mathrm{L}$ of $\mathrm{MHB}$ or SDB and $5 \mu \mathrm{L}$ of inoculum for final concentrations ranging from 0.0625 to $2048 \mu \mathrm{g} / \mathrm{mL}$. The inoculum was standardized to $2.5 \times 10^{5}$ cells $/ \mathrm{mL}$ for yeast and $10^{6} \mathrm{CFU} / \mathrm{mL}$ for bacteria (instead of $1.5 \times 10^{6} \mathrm{CFU} / \mathrm{mL}$ ) using a JENWAY $6105 \mathrm{UV} /$ Vis spectrophotometer. The final concentration of DMSO in each well was $<1 \%$ (preliminary analyzes with $1 \%(\mathrm{v} / \mathrm{v})$ DMSO did not inhibit the growth of the test organisms). The negative control well consisted of $195 \mu \mathrm{L}$ of MHB or SDB and $5 \mu \mathrm{L}$ of the standard inoculum. The plates were covered with sterile lids and then shaken to mix the contents of the wells with a plate shaker and incubated at $37^{\circ} \mathrm{C}$ for $24 \mathrm{~h}$ (for bacteria) or $48 \mathrm{~h}$ (for yeast). The MIC values of the samples were determined by adding $50 \mu \mathrm{L}$ of a solution of MTT (3-(4,5-dimethylthiazol-2-yl)-2,5-diphenyltetrazolium bromide) at $0.2 \mathrm{mg} / \mathrm{mL}$ followed by incubation at $37^{\circ} \mathrm{C}$ for $30 \mathrm{mi}$ nutes. This test is based on enzymatic reduction of the lightly colored tetrazolium salt to its formazan of intense purple-blue color. MIC values were defined as the lowest sample concentrations that prevented this color change indicating complete inhibition of microbial growth. For determination of the MMC values, a portion of liquid $(5 \mu \mathrm{L})$ was taken from each well which showed no growth of microorganism on Mueller Hinton Agar or SDA and incubated at $37^{\circ} \mathrm{C}$ for $24 \mathrm{~h}$ (for bacteria) or $37^{\circ} \mathrm{C}$ for $48 \mathrm{~h}$ (for yeasts). The lowest concentrations that gave no growth after this subculture were taken as MMC values. Vancomycin (Sigma-Aldrich, Steinheim, Germany) and Fluconazole (Merck, Darmstadt, Germany) were used as positive controls for bacteria and yeasts respectively. 


\section{Results and Discussion}

The acetylation and methylation reactions carried out on 3-O- $\beta$-D-glucopyranosyl-( $1 \rightarrow 2)$ - $\beta$-D-glucuronopyranosyl oleanolic acid (1) using pyridine-acetic anhydride mixture and diazomethane, led to a previously undescribe hemisynthetic derivative (2). The yield of synthesis (85.6\%) suggests a successful conversion of compound 1 to compound 2 . However, the loss of $14.4 \%$ was probably due to the purification process. The structure of compound 2 was established by interpretation of spectroscopic and spectrometric data followed by a comparison with those of the substrate (1). In fact, it was obtained as white powder which reacted positively with Liebermann-burchard and Molisch reagents. Its positive HR-TOFESIMS spectrum exhibited a sodium adduct peak at m/z 1041.5044 [M $+\mathrm{Na}]^{+}$(calcd. for $\mathrm{C}_{53} \mathrm{H}_{78} \mathrm{O}_{19} \mathrm{Na}$ 1014.5035) corresponding to the molecular formula $\mathrm{C}_{53} \mathrm{H}_{78} \mathrm{O}_{19}$. Comparison of its ${ }^{1} \mathrm{H}$ and ${ }^{13} \mathrm{C}$ NMR data with those of compound 1 (Table 1) indicated the oleanane nature of aglycone moiety. However, the main difference was observed in the sugar moiety. Indeed, in addition to the signal of sugar we have on the ${ }^{1} \mathrm{H}$ NMR spectrum (Table 2), the signals at $\delta_{\mathrm{H}}$ : 1.98 (H-3"-OAc, s), 2.02 (H-4"-OAc, s), 2.06 (H-2"/6"-OAc, s), 2, 08 (H-4'-OAc, $s)$ attributed to the methyl proton of acetyl groups and a signal at $\delta_{\mathrm{H}} 3.70$ $\left(6^{\prime}-\mathrm{OCH}_{3}, s\right)$ assigned to a proton of methoxy group. These informations were confirmed on its ${ }^{13} \mathrm{C}$ NMR spectrum (Table 2) in which we observe the signals of five acetyl groups at $\delta_{\mathrm{C}}$ : [170.5 $\left.(\mathrm{CO}), 19.3\left(\mathrm{CH}_{3}\right)\right]$, [170.0 (CO), $\left.19.3\left(\mathrm{CH}_{3}\right)\right]$, [170.2 (CO), $19.2\left(\mathrm{CH}_{3}\right)$ ], [169.9 (CO); $\left.19.2\left(\mathrm{CH}_{3}\right)\right]$, [170.9 (CO); $\left.19.4\left(\mathrm{CH}_{3}\right)\right]$, and a signal of methoxy group at $\delta_{\mathrm{C}} 51,6\left(\mathrm{CH}_{3}\right)$.

Positions of the five acetyl groups were determined using HMBC spectrum through the correlations observed between the protons of sugars at $\delta_{\mathrm{H}}: 4.82$ (H-4'), 4.88 (H-2"), $5.24\left(\mathrm{H}-3^{\prime \prime}\right), 5.00\left(\mathrm{H}-4^{\prime \prime}\right), 4.30$ (H-6") and the carbonyls of acetyl groups at $\delta_{\mathrm{C}}$ : $170.5,170.0,170.2,169.9,170.9$ respectively (Scheme 2 ).

In addition to these correlations we observed another between proton at $\delta_{\mathrm{H}}$ $3.70\left(6^{\prime}-\mathrm{OCH}_{3}\right)$ and carbonyl of glucuronic acid at $\delta_{\mathrm{C}} 168.8$ confirming the methylation of carboxylic function. Thus, the structure of compound 2 was established as: 4',2",3",4",6"-penta- $O$-acetyl-6'- $O$-methyl-3- $O-\beta$-D-glucopyranosyl$(1 \rightarrow 2)$ - $\beta$-D-glucuronopyranosyl oleanolic acid trivially named acetomethoxysaponin whose formation mechanism are proposed in Scheme 3 and Scheme 4.

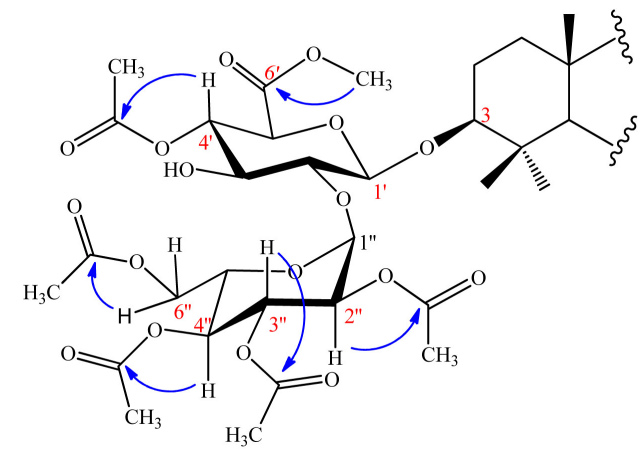

Scheme 2. Key HMBC of sugar moiety of compound 2. 
Table $1 .{ }^{1} \mathrm{H}$ RMN (DMSO- $d_{6}, 600 \mathrm{MHz}$ ) and ${ }^{13} \mathrm{C}$ NMR (DMSO- $d_{6}, 150 \mathrm{MHz}$ ) data of aglycon moiety of compounds 1 and 2.

\begin{tabular}{|c|c|c|c|c|}
\hline \multicolumn{3}{|c|}{ Compound 1} & \multicolumn{2}{|r|}{ Compound 2} \\
\hline Positions & $\delta_{\mathrm{C}}$ & $\delta_{\mathrm{H}}(m u l t ;)$ & $\delta_{\mathrm{C}}$ & $\delta_{\mathrm{H}}(m u l t ;)$ \\
\hline \multicolumn{5}{|l|}{ Aglycon } \\
\hline 1 & 38.5 & $1.48(1 \mathrm{H}, m), 0.90(1 \mathrm{H}, m)$ & 38.3 & $1.62(1 \mathrm{H}, m), 0.97(1 \mathrm{H}, m)$ \\
\hline 2 & 27.4 & $0.97(1 \mathrm{H}, m), 1.63(1 \mathrm{H}, m)$ & 25.5 & $1.83(1 \mathrm{H}, m), 1.71(1 \mathrm{H}, m)$ \\
\hline 3 & 89.0 & $3.01(1 \mathrm{H}, \mathrm{m})$ & 90.4 & $3.14(d d ; 11.6 ; 4.5)$ \\
\hline 4 & 37.7 & - & 38.9 & - \\
\hline 5 & 55.4 & $0.70(1 \mathrm{H}, m)$ & 55.6 & $0.79(1 \mathrm{H}, m)$ \\
\hline 6 & 18.2 & $1.29(1 \mathrm{H}, m), 1.46(1 \mathrm{H}, m)$ & 17.9 & $1.62(1 \mathrm{H}, m), 1.42(1 \mathrm{H}, m)$ \\
\hline 7 & 32.6 & $1.42(2 \mathrm{H}, m)$ & 32.6 & $1.54(1 \mathrm{H}, m), 1.34(1 \mathrm{H}, m)$ \\
\hline 8 & 39.3 & - & 39.2 & - \\
\hline 9 & 47.5 & $1.49(1 \mathrm{H}, m)$ & 47.5 & $1.59(1 \mathrm{H}, m)$ \\
\hline 10 & 37.0 & - & 36.5 & - \\
\hline 11 & 23.1 & $1.79(2 \mathrm{H}, m)$ & 23.1 & $1.91(1 \mathrm{H}, m)$ \\
\hline 12 & 122.1 & $5.16(1 \mathrm{H}, t, 4.2)$ & 122.3 & $5.26(1 \mathrm{H}, t, 4.2)$ \\
\hline 13 & 144.0 & - & 143.8 & - \\
\hline 14 & 41.6 & - & 41.9 & - \\
\hline 15 & 27.7 & $1.09(1 \mathrm{H}, m), 1.66(1 \mathrm{H}, m)$ & 27.4 & $1.79(1 \mathrm{H}, m), 1.09(1 \mathrm{H}, m)$ \\
\hline 16 & 23.4 & $1.42(1 \mathrm{H}, m), 1.79(1 \mathrm{H}, m)$ & 22.7 & $2.03(1 \mathrm{H}, m), 1.61(1 \mathrm{H}, m)$ \\
\hline 17 & 46.6 & - & 46.2 & - \\
\hline 18 & 41.3 & $2.74(1 \mathrm{H}, d d, 13.7,4.0)$ & 41.3 & $2.87(d d, 13.7,3.9)$ \\
\hline 19 & 45.8 & $1.59(1 \mathrm{H}, m), 1.03(1 \mathrm{H}, m)$ & 45.9 & $1.71(1 \mathrm{H}, m), 1.13(1 \mathrm{H}, m)$ \\
\hline 20 & 30.6 & - & 30.2 & - \\
\hline 21 & 33.8 & $1.12(1 \mathrm{H}, m), 1.31(1 \mathrm{H}, m)$ & 33.5 & $1.22(1 \mathrm{H}, m), 1.41(1 \mathrm{H}, m)$ \\
\hline 22 & 32.3 & $1.22(1 \mathrm{H}, m), 1.41(1 \mathrm{H}, m)$ & 32.4 & $1.76(1 \mathrm{H}, m), 1.56(1 \mathrm{H}, m)$ \\
\hline 23 & 28.1 & $0.75(3 \mathrm{H}, s)$ & 27.0 & $1.12(3 \mathrm{H}, s)$ \\
\hline 24 & 15.6 & $0.97(3 \mathrm{H}, s)$ & 15.4 & $0.87(3 \mathrm{H}, s)$ \\
\hline 25 & 15.3 & $0.85(3 \mathrm{H}, s)$ & 14.5 & $0.97(3 \mathrm{H}, s)$ \\
\hline 26 & 16.8 & $0.68(3 \mathrm{H}, s)$ & 16.2 & $0.83(3 \mathrm{H}, s)$ \\
\hline 27 & 26.0 & $1.08(3 \mathrm{H}, s)$ & 25.0 & $1.18(3 \mathrm{H}, s)$ \\
\hline 28 & 179.2 & - & 180.4 & - \\
\hline 29 & 33.1 & $0.88(3 \mathrm{H}, s)$ & 32.2 & $0.93(3 \mathrm{H}, s)$ \\
\hline 30 & 23.6 & $0.87(3 \mathrm{H}, s)$ & 22.6 & $0.96(3 \mathrm{H}, s)$ \\
\hline
\end{tabular}




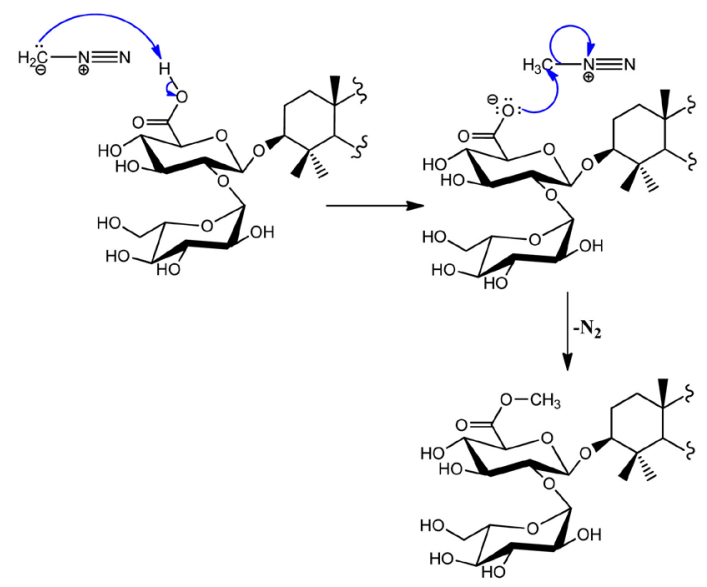

Scheme 3. Methylation mechanism of compound 2.

Table 2. ${ }^{1} \mathrm{H}$ RMN (DMSO- $d_{6}, 600 \mathrm{MHz}$ ) and ${ }^{13} \mathrm{C}$ NMR (DMSO- $d_{6}, 150 \mathrm{MHz}$ ) data of sugar moiety of compounds 1 and 2 .

\begin{tabular}{|c|c|c|c|c|}
\hline \multicolumn{3}{|c|}{ Compound 1} & \multicolumn{2}{|r|}{ Compound 2} \\
\hline C-3 Glu & $\delta_{\mathrm{C}}$ & $\delta_{\mathrm{H}}(m u l t, \lambda)$ & $\delta_{\mathrm{C}}$ & $\delta_{\mathrm{H}}(m u l t, \lambda)$ \\
\hline $1^{\prime}$ & 104.1 & $4.24(1 \mathrm{H}, d, 7.2)$ & 103.4 & $4.53(1 \mathrm{H}, d, 7.6)$ \\
\hline $2^{\prime}$ & 81.8 & $3.30(1 \mathrm{H}, m)$ & 78.3 & $3.66(1 \mathrm{H}, d d, 9.2,7.6)$ \\
\hline $3^{\prime}$ & 77.1 & $3.32(1 \mathrm{H}, m)$ & 74.4 & $3.74(1 \mathrm{H}, t, 9.2)$ \\
\hline $4^{\prime}$ & 72.4 & $3.07(1 \mathrm{H}, \mathrm{m})$ & 72.3 & $4.82(1 \mathrm{H}, d d, 10.0,9.2)$ \\
\hline $5^{\prime}$ & 73.5 & $3.14(1 \mathrm{H}, m)$ & 71.6 & $4.04(1 \mathrm{H}, d, 10.0)$ \\
\hline $6^{\prime}$ & 172.3 & - & 168.8 & - \\
\hline Glc & & & Glc & \\
\hline $1^{\prime \prime}$ & 104.5 & $4.41(1 \mathrm{H}, \mathrm{d}, 7.5)$ & 100.3 & $5.13(1 \mathrm{H}, d, 8.0)$ \\
\hline $2^{\prime \prime}$ & 75.7 & $2.99(1 \mathrm{H}, m)$ & 72.1 & $4.88(1 \mathrm{H}, m)$ \\
\hline $3 "$ & 77.2 & $3.03(1 \mathrm{H}, \mathrm{m})$ & 73.0 & $5.24(1 \mathrm{H}, \mathrm{t}, 9.5)$ \\
\hline $4^{\prime \prime}$ & 70.2 & $3.14(1 \mathrm{H}, m)$ & 68.4 & $5,00(1 \mathrm{H}, t, 9.7)$ \\
\hline $5 "$ & 76.3 & $3.15(1 \mathrm{H}, m)$ & 71.3 & $3.83(1 \mathrm{H}, \mathrm{m})$ \\
\hline 6" & 61.1 & $3.61(1 \mathrm{H}, m), 3.45(1 \mathrm{H}, m)$ & 61.8 & $\begin{array}{l}4.30(1 \mathrm{H}, d d, 12.2,4.1) \\
4.11(1 \mathrm{H}, d d, 12.2,4.1)\end{array}$ \\
\hline $4^{\prime}-\mathrm{OAc}$ & & & $\begin{array}{l}170.5 \\
19.3\end{array}$ & $2.08(3 \mathrm{H}, s)$ \\
\hline 6'-OMe & & & 51.6 & $3.70(3 \mathrm{H}, s)$ \\
\hline 2"-OAc & & & $\begin{array}{l}170.0 \\
19.3\end{array}$ & - \\
\hline 3"-OAc & & & $\begin{array}{c}170.2 \\
19.2\end{array}$ & $1.98(3 \mathrm{H}, s)$ \\
\hline 4"-OAc & & & $\begin{array}{c}169.9 \\
19.2\end{array}$ & $2.02(3 \mathrm{H}, s)$ \\
\hline 6"-OAc & & & $\begin{array}{c}170.9 \\
19.4\end{array}$ & $2.06(3 \mathrm{H}, s)$ \\
\hline
\end{tabular}



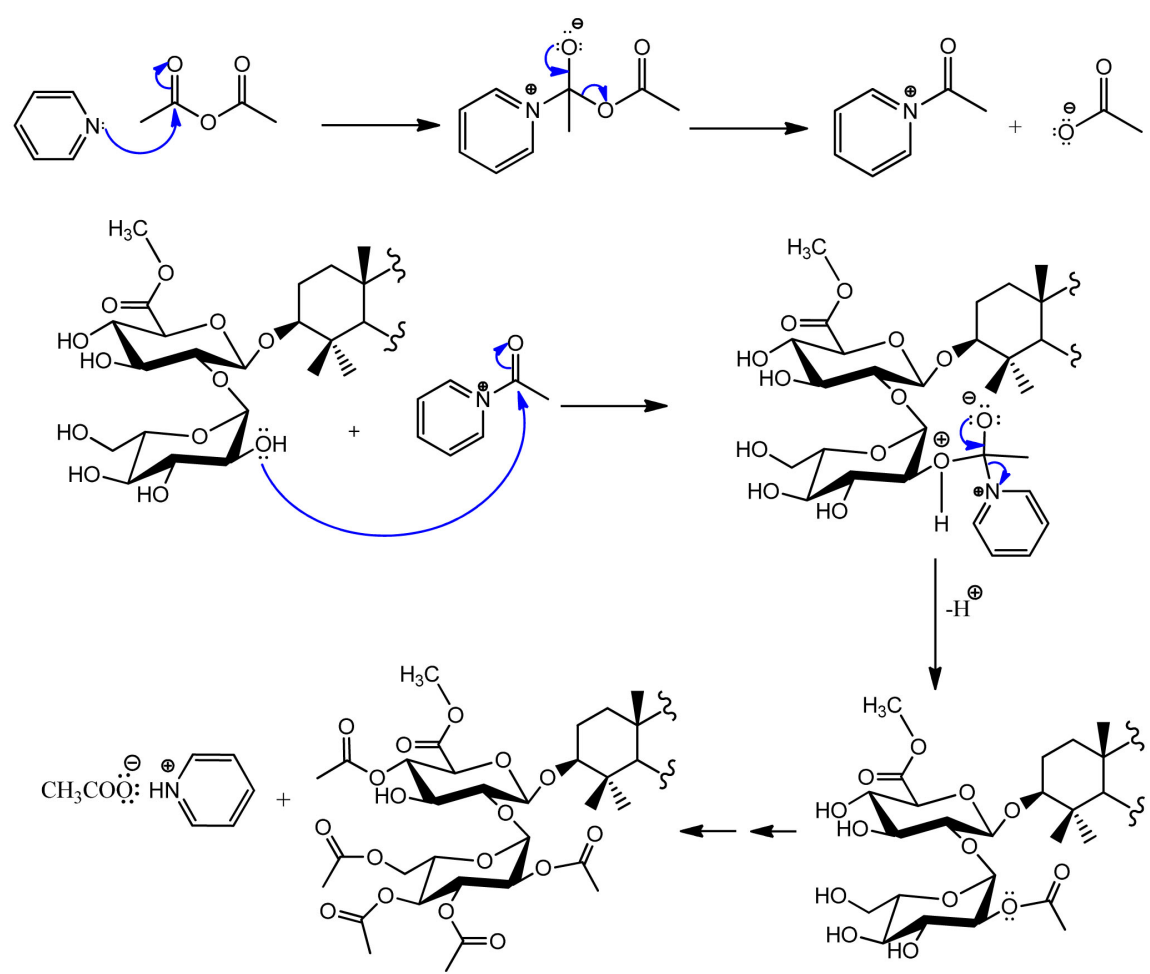

Scheme 4. Acetylation mechanism of compound 2.

After structural elucidation of hemisynthetic saponin, the antimicrobial activities of substrate and reaction product were carried out against three strains of bacteria (Escherichia coli S2, Staphylococcus aureus ATCC 25,923 and Shigella flexneri SDINT) and three yeast strains (Candida tropicalis, Candida albicans ATCC 9002 and Cryptococcus neoformans IP 95,026) selected on the basis of their relevance as human pathogens. The results are presented in Table 3.

In general, bacterial and fungal strains were more susceptible to the effects of the reaction product compared to the substrate. In fact, reaction product presented the lowest values of MIC againt $E$. coli $(\mathrm{MIC}=16 \mu \mathrm{g} / \mathrm{mL}$ ), S. aureus (MIC $=8 \mu \mathrm{g} / \mathrm{mL})$, C. tropicalis $(\mathrm{MIC}=16 \mu \mathrm{g} / \mathrm{mL})$ C. albicans $(\mathrm{MIC}=8 \mu \mathrm{g} / \mathrm{mL})$ compare to the substrate against the same microbial strains: E. coli $(\mathrm{MIC}=32$ $\mu \mathrm{g} / \mathrm{mL}$ ), S. aureus (MIC $=16 \mu \mathrm{g} / \mathrm{mL})$, C. tropicalis $(\mathrm{MIC}=32 \mu \mathrm{g} / \mathrm{mL}$ ), C. albicans $(\mathrm{MIC}=16 \mu \mathrm{g} / \mathrm{mL}$ ) whereas the two samples presented the same MIC values $(\mathrm{MIC}=16$ and $8 \mu \mathrm{g} / \mathrm{mL})$ respectively against $S$. flexneri and $C$. neoformans. The antibacterial activity of compound 2 against $E$. coli and $S$. flexneri was less or equal to those of vancomycin ( $\mathrm{MIC}=16-32 \mu \mathrm{g} / \mathrm{mL}$ ) used as reference antibiotic. The results of the present study showed that, the antimicrobial activities of compounds 1 and 2 varied with the bacterial and fungal strains. These variations may be due to genetic differences between the tested microorganisms. Furthermore, According to Li et al., 2009 [16], environmental conditions such as $\mathrm{pH}$ have a great influence on antimicrobial activities of saponins. Acetylation and methylation reactions of hydroxyl group carried out in this study contribute to modify the $\mathrm{pH}$ of the final solution containing compound 2 . This difference of 
Table 3. Antimicrobial activity (MIC and MMC in $\mu \mathrm{g} / \mathrm{mL}$ ) of substrate and reaction product as well as antimicrobial reference drugs.

\begin{tabular}{cccccccc}
\hline \multirow{2}{*}{ Compounds } & $\begin{array}{c}\text { Inhibition } \\
\text { parameters }\end{array}$ & $\begin{array}{c}E . \\
\text { coli }\end{array}$ & $\begin{array}{c}S . \\
\text { flexneri }\end{array}$ & $\begin{array}{c}S . \\
\text { aureus }\end{array}$ & $\begin{array}{c}C . \\
\text { tropicalis }\end{array}$ & $\begin{array}{c}C . \\
\text { albicans }\end{array}$ & $\begin{array}{c}C . \\
\text { neoformans }\end{array}$ \\
\hline \multirow{2}{*}{1} & MIC & 32 & 16 & 16 & 32 & 16 & 8 \\
& MMC & 64 & 32 & 16 & 64 & 32 & 16 \\
& MMC/MIC & 2 & 2 & 1 & 2 & 2 & 2 \\
\hline \multirow{2}{*}{2} & MIC & 16 & 16 & 8 & 16 & 8 & 8 \\
& MMC & 16 & 32 & 16 & 32 & 16 & 8 \\
\multirow{2}{*}{ Ref } & MMC/MIC & 1 & 2 & 2 & 2 & 2 & 1 \\
& MIC & 32 & 16 & 0.5 & 0.5 & 1 & 2 \\
& MMC & 32 & 16 & 0.5 & 0.5 & 1 & 2 \\
& MMC/MIC & 1 & 1 & 1 & 1 & 1 & 1
\end{tabular}

MIC: Minimal Inhibitory Concentration; MMC Minimal Microbicide Concentration; ${ }^{*}$ : Fluconazole for yeasts and Vancomycin for bacteria.

$\mathrm{pH}$ due to the chemical transformations would explain the difference observed at the level of the antimicrobial activities of the two compounds against the microbial strains tested. These results could also be explained in terms of antimicrobial action mechanism of saponin. According to Dourmashkin et al. (1962), [17] the mechanism of antimicrobial action of saponins is based on perturbation of membrane cell by the formation of pores. Based on this observation, Bangham and Horne (1962) [18] and Glauert et al. (1962) [19], concurrently reported that, the presence of cholesterol on the target membrane is essential for the saponins to induce pore formation. According to their reports, saponins and cholesterol associated spontaneously into a micelle-like complex and the hydrophilic sugar moieties are thought to be located in the central of the complex and leads to the development of aqueous pores. Such pores can increase the permeability of membrane and enabling the macromolecules and ions to pass through the membrane bilayer. The results of these studies suggest that, the acetyl and methyl groups have great influence on the spontaneous association between saponin and cholesterol and consequently increases the antimicrobial activities of reaction product.

\section{Conclusion}

The overall results of the present study indicate that, the new hemisynthetic saponin obtain after acetylation and methylation reactions are most active than the substrate against the tested microorganisms. Given the results, acetylation and methylation reactions followed by evaluation of antimicrobial activities have to be performed on a wide range of oleanane saponins.

\section{Acknowledgements}

The authors are grateful to the "Service Commun d'Analyses" and "Groupe 
Isolement et Structure", of "Institut de Chimie Moléculaire de Reims" for the spectroscopic and spectrometric analysis on the ESIMS and NMR equipement of the PlAnet Platform.

\section{Conflicts of Interest}

Authors declare no conflict of interest.

\section{Availability of Data and Materials}

The datasets used and/or analyzed during the current study are available from the corresponding author on reasonable request.

\section{References}

[1] Van Dyck, S., Flammang, P., Meriaux, C., Bonnel, D., Salzet, M. and Fournier, I. (2010) Localization of Secondary Metabolites in Marine Invertebrates: Contribution of MALDI MSI for the Study of Saponins in Cuvierian Tubules of Holothuria forskali. PLoS ONE, 5, e13923. https://doi.org/10.1371/journal.pone.0013923

[2] Hostettmann, K.A. and Marston, A. (1995) Saponins. Cambridge University Press, Cambridge, 548. https://doi.org/10.1017/CBO9780511565113

[3] Price, K.R., Johnson, I.T. and Fenwick, G.R. (1987) The Chemistry and Biological Significance of Saponins in Food and Feeding Stuffs. Critical Reviews in Food Science and Nutrition, 26, 127-135. https://doi.org/10.1080/10408398709527461

[4] Zhang, S. and Hu, Z. (1985) Anti-Ulcerogenic Effects of Ginseng Flower Saponins in the Rat Zhongyao Tongbao 10: 331. Chemical Abstracts, 104, 512.

[5] Okubo, K., Kudou, S., Uchida, T., Yoshiki, Y., Yoshikoshi, M. and Tonomura, M. (1994) Soybean Saponins and Isoflavonoids: Structure and Antiviral Activity against Human Immunodeficiency Virus in Vitro. In: Food Phytochemicals for Cancer Prevention I, ACS Symposium Series, Vol. 546, American Chemical Society, Washington DC, Chapter 26, 330-339. https://doi.org/10.1021/bk-1994-0546.ch026

[6] Just, M.J., Recsio, M.G., Gner, R.M., Cuellar, M.J., Marez, S., Bilia, A.R. and Rios, J. (1998) Anti-Inflammatory Activity of Unusual Lupane Saponins from Buleurum fruiticescens. Planta Medica, 64, 404-407. https://doi.org/10.1055/s-2006-957469

[7] Woldemichael, G.M. and Wink, M. (2001) Identification and Biological Activities of Triterpenoid Saponins from Chenopodium quinoa. Journal of Agricultural and Food Chemistry, 49, 2327-2332. https://doi.org/10.1021/jf0013499

[8] Sparg, S.G., Light, M.E. and Van, S.J. (2004) Biological Activities and Distribution of Plant Saponins. Journal of Ethnopharmacology, 94, 219-243. https://doi.org/10.1016/j.jep.2004.05.016

[9] Fouedjou, T.R., Teponno, R.B., Quassinti, L., Bramucci, M., Petrelli, D., Vitali, L.A., Fiorini, D., Tapondjou, A.L. and Barboni, L. (2014) Steroidal Saponins from the Leaves of Cordyline fruticosa (L.) A. Chev. and Their Cytotoxic and Antimicrobial Activity. Phytochemistry Letters, 7, 62-68. https://doi.org/10.1016/j.phytol.2013.10.001

[10] Tagousop, C.N., Tamokou, J.D.D., Kengne, C.I., Ngnokam, D. and VoutquenneNazabadioko, L. (2018) Antimicrobial Activities of Saponins from Melanthera elliptica and Their Synergistic Effects with Antibiotics against Pathogenic Phenotypes. Chemistry Central Journal, 12, 97.

https://doi.org/10.1186/s13065-018-0466-6 
[11] Deore, S.L., Khadabadi, S.S., Chittam, K.P., Bhujade, P.G., Wane, T.P., Nagpurkar, Y.R., Chanekar, P.D. and Jain, R.G. (2009) Properties and Pharmacological Applications of Saponins. Pharmacologyonline, 2, 61-84.

[12] Wang, R.F., Li, J., Hu, H-J., Li, J., Yang, Y.-B., Yang, L. and Wang, Z.-T. (2016) Chemical Transformation and Target Preparation of Saponins in Stems and Leaves of Panax notoginseng. Journal of Ginseng Research, 1-7.

[13] Penders, A. and Delaude, C. (1994) Triterpenoid Saponins from Melanthera scandens. Phytochemistry, 37, 821-825. https://doi.org/10.1016/S0031-9422(00)90364-9

[14] Clinical and Laboratory Standards Institute (1997) Reference Method for Broth Dilution Antifungal Susceptibility Testing of Yeasts. Approved Standard (CLSI Document M27-A), Clinical and Laboratory Standards Institute, Wayne.

[15] Clinical and Laboratory Standards Institute (2009) Methods for Dilution Antimicrobial Susceptibility Tests for Bacteria That Grow Aerobically; Approved Standard Eighth Edition (CLSI Document M07-A8). Clinical and Laboratory Standards Institute, Wayne.

[16] Li, Y., Du, Y. and Zou, C. (2009) Effects of $\mathrm{pH}$ on Antioxidant and Antimicrobial Properties of Tea Saponins. European Food Research and Technology, 228, 1023-1028. https://doi.org/10.1007/s00217-009-1014-3

[17] Dourmashkin, R.R., Dougherty, R.M. and Harris, R.J.C. (1962) Electron Microscopic Observations on Rous sarcoma Virus and Cell Membranes. Nature, 194, 1116-1119. https://doi.org/10.1038/1941116a0

[18] Bangham, A.D. and Horne, R.W. (1962) Action of Saponin on Biological Cell Membranes. Nature, 196, 952-953. https://doi.org/10.1038/196952a0

[19] Glauert, A.M., Dingle, J.T. and Lucy, J.A. (1962) Action of Saponin on Biological Cell Membranes. Nature, 196, 953-955. https://doi.org/10.1038/196953a0 